\title{
UNDERSTANDING THE SOCIAL SCIENCES
}

\author{
Titu-Marius I. Băjenescu*, ORCID ID: 0000-0002-9371-6766 \\ Swiss Technology Association, Electronics Group Switzerland \\ *Coresponding autor: Titu-Marius I. Băjenescu, tmbajenesco@gmail.com
}

Received: 09. 29. 2021

Accepted: 11. 02. 2021

\begin{abstract}
Old age is difficult to define, so many terms overlap or clash with each other, all of which raise a number of issues: the elderly, the third age, the fourth age, pensioners, etc. It is not easy to determine the threshold for entering the period of life commonly known as old age. One thing is certain, old age has changed profoundly. From now on, it has become for everyone, albeit with profound inequalities, a normal stage of life. Social security systems combined with the considerable progress in medicine have made it possible to increase the length of retirement. Whereas in 1950 a man retiring at 65 could expect to live for about 12 years, today life expectancy at 60 is over 20 years for men and over 25 years for women. However, this simple observation has much more complex consequences in terms of the social identity, integration and social behaviour of these new population groups. Despite an ageing population, Switzerland has a total labour force of 4.706 million people. In the fourth quarter of 2019, the participation rate of the population aged 15 and over was $68.1 \%$. This puts the country in second place in Europe behind Iceland (79.9\%). Switzerland's neighbouring states have significantly lower levels (Germany: 62.6\%, Austria: 61.4\%; France: 55.5\%, Italy: 49.9\%). In particular, Switzerland has one of the highest rates of employed women in Europe. The percentage of employed women increased significantly between 2010 and 2019, from $56.9 \%$ to $60 \%$.
\end{abstract}

Keywords: Science, social science, social intelligence, embeddedness, economic imperialism, social research, empirical social research, sociology, ageing and sociology, economic sociology, sociability.

Rezumat. Bătrânețea este dificil de definit, astfel încât mulți termeni se suprapun sau se ciocnesc între ei, toți ridicând o serie de probleme: vârstnici, bătrâni, vârsta a treia, vârsta a patra, seniori, pensionari, persoane în vârstă etc. fiind uşor de determinat pragul de intrare în perioada de viață cunoscută în mod obișnuit sub numele de bătrânețe. Un lucru este cert, bătrânețea s-a schimbat profund. De acum înainte, ea a devenit pentru toată lumea, deși cu profunde inegalități, o etapă normală a vieții. Sistemele de securitate socială, combinate cu progresele considerabile ale medicinei, au făcut posibilă creșterea duratei de pensie. Dacă în 1950 un bărbat care se pensionează la 65 de ani se poate aștepta să trăiască aproximativ 12 ani, astăzi speranța de viață la 60 de ani este de peste 20 de ani pentru bărbați și de peste 25 de ani pentru femei. Această simplă constatare are însă consecințe mult mai complexe în ceea ce privește identitatea socială, integrarea și comportamentul social al acestor noi 
grupuri de populație. În ciuda îmbătrânirii populației, Elveția are o forță de muncă totală de 4.706 milioane de persoane. În al patrulea trimestru din 2019, rata de participare a populației cu vârsta de 15 ani și peste a fost de 68,1\%. Aceasta plasează țara pe locul al doilea în Europa, după Islanda (79,9\%). Statele vecine ale Elveției au niveluri semnificative mai scăzute (Germania: 62,6\%, Austria: 61,4\%; Franța: 55,5\%, Italia: 49,9\%). În special, Elveția are una dintre cele mai ridicate rate de femei angajate din Europa. Procentul de femei angajate a crescut semnificativ între 2010 și 2019, de la 56,9\% la 60\%.

Cuvinte cheie: Ştiinţă, ştiinţă socială, inteligenţă socială, dereglementări ale pieţelor, imperialismul economic, cercetarea socială empirică, sociologia, îmbătrânirea şi sociologia, sociologia economică, sociabilitate.

\section{Introduction}

The term sciences is a collective term for all those scientific disciplines that deal with the phenomena of people living together in society [1]. Social sciences are also referred to as social sciences [2]. The word sociology is derived from both Latin and Greek origins. The Latin

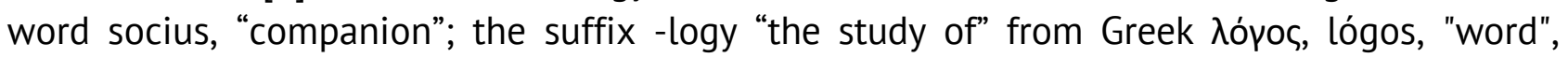
"knowledge". It was first coined in 1780 by the French essayist Emmanuel-Joseph Sieyès (1748 - 1836) in an unpublished manuscript. Sociology was later defined independently by the French philosopher of science, Auguste Comte (1798 - 1857) in 1838 as a new way of looking at society.

Classically, the following disciplines are counted among the social sciences: Anthropology (social and cultural anthropology) and social philosophy, social ethics [3], social history, social psychology, sociology [4], pedagogy, educational science incl., empirical social research [5], population science, ethnology (study of peoples), anthropogeography, art science, cultural studies, religious studies, religious education, law (jurisprudence) [6], political science, media studies, communication studies, linguistics , economics.

With regard to the methods and approaches used, there are overlaps between the social sciences, the humanities and the natural sciences. However, while the social sciences focus on the processes of human coexistence, the humanities are concerned with the cultural products of human existence, such as language, philosophy and mathematics. In contrast, the view of the natural sciences can be characterized as object-oriented. They try to explain the interrelationships, the structure and the emergence and decay of inanimate and animate nature.

Associated disciplines: Classically, the following disciplines are counted among the social sciences: Anthropology (social and cultural anthropology) and social philosophy, social ethics [3], social history, social psychology, sociology [4], pedagogy, educational science incl. pedagogy, empirical social research [5], population science, ethnology (study of peoples), anthropogeography, art science, cultural studies, religious studies, religious education, law (jurisprudence) [6], political science, media studies, communication studies, linguistics, economics.

Delimitations: With regard to the methods and approaches used, there are overlaps between the social sciences, the humanities and the natural sciences. However, while the social sciences focus on the processes of human coexistence, the humanities are concerned with the cultural products of human existence, such as language, philosophy and mathematics. In contrast, the view of the natural sciences can be characterized as object- 
oriented. They try to explain the interrelationships, the structure and the emergence and decay of inanimate and animate nature.

Many people probably like to consume the results of (pseudo-scientific) empirical survey studies in their results of (pseudo-scientific) empirical survey studies. For example, you could take part in a survey on space tourism on the internet pages of New York Times and answer the following question: "With SpaceShipOne the first privately financed space plane has flown into orbit. Now spaceports are being built in the USA or Australia are planned. Off-the-wall tourism plans or realistic market niche?"

After casting one's own vote to answer this question one learns that 27 percent of the visitors to this website who are willing to answer think that space tourism is environmental pollution, space tourism is pollution and a waste of money. This should be banned or restricted. 54 percent of the 268 people who have voted so far think space tourism is a holiday option for wealthy adventurers and is not affordable for ordinary people. In the end 19 per cent of the participants voted for the statement, "A trip to outer space into space is dreamlike and also results in new opportunities for the tourism industry."

Slightly fewer people have also professionally - and that should mean at this point more seriously - with results from empirical studies. For the latter group of people in particular, it is important to know exactly how such data has been and what they can tell us. Four seemingly trivial examples will show what a data consumer has to reckon with.

\section{Social intelligence}

Social intelligence or interpersonal intelligence is the form of intelligence that allows us to understand others (their thoughts, feelings) and to act effectively on them (obtain their support, modify their behaviour) in situations of social interaction.

Basically, social intelligence is a form of intelligence that allows you to understand others and to interact with them adequately (depending on what you want them to do or be).

\section{The goal of the human and social sciences}

The goal of the human and social sciences is to scientifically investigate such issues and, in this way, to arrive at the most reliable knowledge possible [7]. Since social facts are elements of our perceptible experiential reality, the human and social sciences are empirical sciences; they are based on the systematic collection, processing and analysis of empirical data, i.e. of information about the reality of experience (e.g. test scores, physiological measurements, interview recordings, observation protocols).

\section{Development}

The study of the developmental dynamics of capitalist society was at the centre of sociology during its founding phase as an academic subject (1890 - 1920). Émile Durkheim ${ }^{1}$, Karl Marx ${ }^{2}$, Georg Simmel ${ }^{3}$ and Max Weber. Weber developed social theories that focused on the interplay of economy, culture and social structure. In parts, these theories are closely related to the institutionalist theory of the Historical School.

\footnotetext{
1 1893: Sociologist Émile Durkheim outlines the idea of social order maintained by organic and mechanical solidarity in The Division of Labor in Society.

2 1848: In The Communist Manifesto, Karl Marx and Friedrich Engels lay out the effects of capitalism on society.

${ }^{3}$ Philosophe et sociologue allemand, atypique et hétérodoxe, Georg Simmel dépasse les clivages, pratiquant l’interdisciplinarité.
} 
With the formalisation of neoclassical economic theory in the 1920s and 1930s, a division of labour was established between sociology and economic theory, in which sociology dealt primarily with narrowly defined peripheral areas of the economy. The American sociologist Talcott Parsons (1903 - 1979) imagined the division of labour between the two subjects in such a way that economics dealt with the universal principle of the endsmeans relationship in individual action, while sociology sought the origins of these ends in social values. This idea fitted very well with post-war Western capitalist societies, in which the economy appeared as a politically controllable apparatus for the fulfilment of politically set overall social goals. Economic sociologists in the post-war period concentrated primarily on the analysis of the Taylorist organisation of work in companies, the shaping of industrial relations, and the institutional regulation of industries and sectors.

With the crisis of Keynesian macro-control and the beginning deregulation of markets at the end of the 1970s, however, questions about the functioning of markets, the dynamics of competition and the decision-making processes of companies returned to the centre of sociology. This coincided with a crisis of the neoclassical paradigm within economic theory: the standard macroeconomic models offered hardly any explanations for the observed stagflation and the increasingly forced crisis dynamics. From a microeconomic perspective, challenges such as the principal-agent problem, moral hazard and information asymmetries arose. Paradoxically, this crisis of post-war economic theory was accompanied by the expansion of economic thinking in sociology: the economics-inspired rational choice model penetrated into the most diverse fields of sociology. This "economic imperialism" prompted sociologists to counter-react: in dealing with economic phenomena, they wanted to show that the economic model of action already had considerable deficits in explaining its genuine subject area, the economy. With this, however, sociology began to transcend the demarcation of the two disciplines drawn by Talcott Parsons and to deal with the core of economic phenomena again. Based on empirical data, Parsons' social action theory was the first broad, systematic, and generalizable theory of social systems developed in the United States and Europe.

In the USA, the renaissance of economic sociology first became apparent in network and organisational research. The concept of "embeddedness", coined in an influential essay by Mark Granovetter, gained central importance for the new economic sociology, capturing the constitutive connection of economic action with network structures, cognitive patterns and political institutions. In Europe, the renaissance of economic sociology only began in the 1990s. Since then, it has been one of the fast-growing fields of sociology attracting considerable attention.

Observation of a culture or group in its natural setting has long favoured the method of social research. Often associated with anthropology and sociology, researchers have used observation in a variety of settings, from foreign cultures to school classes. By interacting with members of a group or society and participating in its activities and rituals, researchers can study social phenomena from the perspective of an outsider and insider. Because of the nature of social science research, observations occur as part of field research, rather than in a laboratory setting. Observation yields rich descriptive data, but must be carried out with care. One of the major concerns of observation is whether subjects, knowing that they are being observed, change their behaviour or activities. 


\section{Statistical Experiments}

To add scientific rigor to social research, sociologists, political scientists, and others have performed complex statistical analyses in their research, either collecting their own data or using data sets from government agencies or other organizations. Popular social research datasets include the American National Election Studies, the National Longitudinal Survey of Youth, and various types of economic data collected by the U.S. Department of Commerce and the Bureau of Labor Statistics. These and other datasets help researchers use empirical data to test hypotheses and draw conclusions based on quantitative data. Researchers who use data collected by government agencies and others, however, should exercise caution, as these data were likely collected for purposes different from those for which the researcher is using the data.

\section{Empirical Research}

Empirical research cannot be learned by reading books alone. Practical experience in dealing with the instruments of empirical social research cannot be replaced by any textbook, no matter how complete and detailed.

Students of the social sciences or humanities acquire a wide variety of knowledge and skills, depending on the discipline. Independent of all subject content, academic education always also pursues the goal of enabling students to understand, assess and produce scientific knowledge themselves. Methodological competence is necessary for this active participation in gaining scientific knowledge. Because without research methods, science is not possible.

Empirical social and human research is concerned with social and human circumstances, i.e. with the behaviour, experience and coexistence of people as well as with physical and mental characteristics of the human being. In this context, "human" and "social" are not positive-values, but neutral-descriptive terms that refer to the human and the interpersonal.

Questions that are investigated are, for example:

- What are the correlations between personality traits on the one hand and career success on the other?

- Are only children more selfish than siblings? And if so, how does this effect come about?

- Does mammography screening make sense for the early detection of breast cancer, or do misdiagnoses and side effects of the procedure predominate?

- What knowledge and what attitudes towards stem cell research exist in the population of different European countries?

- How widespread is hyperactivity among children and

- How widespread is hyperactivity among children and adolescents in Germany and how is it successfully treated?

- Which campaigns and measures against cigarette smoking are particularly effective and efficient?

- Does the use of violent video games increase aggressiveness?

- What influence do global financial crises have on the prestige of the economic elite? 


\section{Empirical Data}

"Empirical data" is information about the reality of experience that is specifically selected and documented with regard to the research problem. They are with scientific data collection methods (observation, interview, questionnaire, psychological test, physiological measurement, document analysis) using corresponding standardised or non-standardised data collection instruments (observation plan, interview guide, questionnaire, measuring device, etc.). Meaningful data are only meaningful if they are used within the framework of a research process and research design appropriate to the research problem

The data are only meaningful if they have been collected on a suitable sample (or on the entire population) within the framework of a research process and study design appropriate to the research problem, if they have been evaluated appropriately and if they have been interpreted in a theory-related manner.

\section{Ageing and Retirement}

"Old age is not just a word" [8]. Far from being a simple biological fact, it is analysed by the sociologist as a true social and historical construct. In order for old age to become one of the stages in the life cycle, retirement had to be institutionalised, as a new age of life [9] could then take shape outside the labour market. If the "old" are all pensioners, this category is no less disparate, hence the flowering of new expressions: senior citizens, dependent elderly. The words to say it are obviously heavy with meaning. "Senior" is a term invented by marketing to segment and energize the youngest and most solvent part of the group! "Dependent elderly" refers to a medical judgement. And the fourth age is added to the third with the increase in life expectancy. Finally, we are interested in ageing from an individual point of view, adopting a micro-sociological perspective. Ageing can then be approached as a non-linear process, "a combination of commitments and disengagements", but also as an experience. And the ultimate experience is that of death, the last stage of life still too little explored by sociologists.

\section{Ageing and Sociology}

Regardless of the usual assumptions for mortality, fertility and migration, the population of metropolitan France will continue to age at least until 2050. The number of people would grow all the more as age increases: almost tripling for those aged 75 or over and quadrupling for those aged 85 or over. In 2050, one in three inhabitants will be aged 60 or over, compared with one in five in 2005 . The proportion of young people capable of being professional and/or family careers would decrease, as would that of people of working age. Old age is difficult to define, so many terms overlap or clash with each other, all of which raise a number of issues: the elderly, the third age, the fourth age, senior citizens, pensioners, etc. It is not easy to determine the threshold for entering the period of life commonly known as old age. One thing is certain, old age has changed profoundly. From now on, it has become for everyone, albeit with profound inequalities, a normal stage of life. Social security systems combined with the considerable progress in medicine have made it possible to increase the length of retirement.

\section{Society and Ageing}

Parallel to this evolution, the sociological viewpoint has changed. Thus, old age is no longer spoken of as a state but as a process [8]. The ageing of the population is accompanied 
by the isolation of older people and a change in society that public policies must address in a comprehensive manner. The increase in life expectancy is reflected in a sharp rise, at the end of the last century, in the number of older people living alone. This increase is particularly strong at older ages, 80 years and over. The scale of this phenomenon is explained by the changing family situations due to mortality: the death of a spouse in an elderly couple whose children have left usually leaves the surviving spouse alone. Finally, the growing autonomy of older people, made possible by improved health conditions, enables them to stay longer in their homes and to delay their departure into institutions. The proportion of single people rises from just over 20\% for those aged $65-69$ to $30 \%$ for those in their seventies, reaching a peak with over $40 \%$ for those in their eighties.

\section{Economic Sociology}

Economic sociology views economic action as a form of social action [10]. In contrast to modern economic theory, it does not start from the model of the individual's calculation of utility. Rather, economic decisions and transactions are shaped by social influences and collective patterns of interpretation. From the point of view of economic sociology, social origins, norms, routines, networks, organisations and institutions do not only enter into the rational calculation of economic actors as costs, but also create the actors' orientation for action. Accordingly, markets and companies are not understood as aggregations of individual decisions, but as social orders with formative power for economic action [11]. The economic sociological critique of the basic theoretical assumptions of the standard model of economic theory builds on this.

\section{Sociability}

The relationships of senior citizens are marked by advancing age, cessation of activity, the arrival of grandchildren and changes in health status. All these factors gradually modify the contacts they have with their loved ones. Between the ages of 65 and 70, with the growing number of grandchildren, the relationship with the descendants becomes even more intense. The few contacts maintained with colleagues weaken, relations with shopkeepers are maintained and neighbourhood relations are slightly strengthened. From the age of 70 onwards, friendships diminish under the natural effect of the death of relatives and more limited activity. In addition, the weight of physical handicaps and dependency become more and more penalizing. After the age of 80 , friendly and neighbourly contacts diminish significantly [12]. With the loss of autonomy, the over-85s even reduce their relations with shopkeepers and their service relationships. Contacts are concentrated on an increasingly limited number of interlocutors. Only family relationships are maintained.

Asserting that ageing and retirement are primarily social problems does not mean that they are not self-evident. Such a stance must be based on a foundation, otherwise the subsequent analyses will be erroneous and interventions will be out of date. In a first time, it is necessary to define what a social problem is; how a problem is a social problem; and how it can be solved, if it can be qualified as social; then put ageing and retirement into the framework of this problematisation; finally, to consider the practical consequences of this definition and this inclusion in the social resolution, of social intervention and the training of social actors.

The difficulties linked to the age structure are as many as the social problem's amounts; and asserts that economic and social marginalization of a majority of early retirees and pensioners. It finds its origin and its social explanation in the accumulation of inferior 
social positions of exploitation; plus domination at work and in other areas of activity and life by these pluses 50 years old.

The character of the individual or the quality of his or her education will make their influence felt. However, these are aggravating factors and not explanatory factors: highlighting them would mean ignoring and obscuring the priority social aspect of these problems, thus depriving oneself of the means for a sound analysis and moving away from the paths of effective intervention.

To pose a social problem is tantamount to criticising the social reality that structures and maintains it. What makes a social problem is in itself problematic? Let us take the example of retirement conditions: for all those who have worked and lived - not by choice, but more often than not with their bodies defending them - in social positions of greater exploitation and more secure subjugation, and even if retirement sounds to their minds like a deliverance and a reward, the definitive departure from work is nonetheless, socially speaking, an irremediable expulsion of an ageing workforce deemed less competent and less recyclable, especially less profitable on the labour market [13]. In a society where work is a central factor of social integration, retirement thus sanctions their social disqualification and leads them to the margins of exclusion.

Socially explaining the problems and denouncing their seriousness is not enough; it is also necessary to work on their social solution [14,15]. A social problem cannot be solved by purely technical means, by simple organisational arrangements or means. Socially explaining problems and denouncing their seriousness is not enough; it is also necessary to work on their social solution. A social problem cannot be solved by purely technical means, by simple organisational arrangements or means.

\section{Vieillissement and Retirement}

The succession of policies for the social management of ageing and retirement must also be analysed from the point of view of the instituted effect of social relationships, beyond the techniques of defined and drowing up programmes [1, 16].

Gerontological intervention, far beyond its methodological variants, technical forms and immediate results, will not produce the same social effects, depending on the forms and orientations that its agents favour and on the types of social relations in which it is developed and engaged $[17,18]$.

\section{Conclusion concerning vieillissement and retirement}

The succession of policies for the social management of ageing and retirement must also be analysed from the point of view of the instituted effect of social relationships, beyond the techniques of defining needs and drawing up programmes.

Gerontological intervention, far beyond its methodological variants, technical forms and immediate results, will not produce the same social effects, depending on the forms and orientations that its agents favour and on the types of social relations in which it is developed and engaged.

\section{New developments}

Of course, there are always new developments within the constantly (and in recent years even rapidly) growing field of qualitative and interpretative interpretative social research. That would argue for new introductions [9, 12]. But this natural growth and almost inevitable differentiation of the field of the field require, first and foremost, revised new 
editions of the already existing existing introductions, but not yet necessarily a new work. If I despite this comfortable situation, this contribution is another introduction to the theory and practice of qualitative social research (which is not a real introduction in the conventional sense of the word), then for the following reasons:

Firstly, much of what is relevant for the practice of qualitative and interpretative research, if one wants to do it oneself, is often neglected in these introductions, or not dealt with at all in the existing introductions (e.g. history data protection; subjectivity; difference between qualitative, interpretative, reconstructive; comparison of methodological practices etc.) [7].

Secondly, the existing introductions, however competent and comprehensive as they are in detail, are too much and demanded by publishers) to the requirements. This means: they formulate their descriptions mainly in the indicative! In addition, they give the reader a wealth of tips and advice, but also normative guidelines that are ostensibly not part of the author's respective theoretical self-understanding of the author(s), but are anchored in science itself - so the implicit assertion. The impression then arises as if these descriptions and guidelines were self-explanatory, as if all this represented an unquestionable basic knowledge of qualitative and interpretative social research. In this way, these introductions create certainties where sowing doubts would be more appropriate (which, in my opinion, is the task of science) $[14,19]$. The historical and theoretical conditionality of the respective individual presentations is not only made visible, but rather concealed, which has the effect of the impression is created that there is a secure body of knowledge within qualitative and qualitative and interpretative social research. Secured knowledge, on the other hand, only exists within a certain theoretical and/or methodological perspective [20].

The third reason for presenting here another view on qualitative and interpretative social research, albeit different. The existing introductions tend to be more theoretical generally determine practices and catalogue the practices of qualitative social research, present case studies, on the basis of which they plausibilise selected problems of qualitative and interpretative social research $[15,21]$. A combination of theoretical discussion and practical interpretative work has (in my view) not yet been really succeeded. Here, I venture a new attempt, even at the risk of also failing, as well. This attempt is made from a sociological perspective, which belongs to the theoretical program of communicative constructivism. Methodologically, from the point of view of an interpretative, hermeneutic social research.

\section{References}

1. Caradec Vincent. 2008. Sociology of old age and aging, 2nd edition, Armand Collin, Paris

2. Wilsonb. 1985. Secularization: the inherited model. In Hammond, P. E. (ed.). The sacred in a secular age: toward revision in the scientific study of religion. Berkeley, CA: University of California Press,

3. Döring Nicola, Börtz Jürgen, - Forschungsmethoden und Evaluation in den Sozial- und Humanwissenschaften, 5. Auflage, Springer, 2016

4. Borgman C. L. 2007. Scholarship in the Digital Age: Information, Infrastructure and the Internet. MIT Press

5. Ess C. 2002. Ethics and Information Technology, Introduction. Vol. 4, No. 3, pp. 177-188

6. LYONS. 1985. The steeple's shadow: on the myths and realities of secularization. Londoner

7. Otero Marcelo, 2006, Michel Foucault, unclassifiable classic, Michel Foucault: sociologist? Sociology and Societies, Volume 38, Issue 2, Fall 2006.

8. Alexander J. 1987. The centrality of the classics, in A. Giddensand \& J. Turner (eds.), Social Theory Today, Stanford: Stanford University Press, 11-57.

9. O'toole R., 2001. Classics in the sociology of religion: an ambiguous legacy, Richard K. Fenn (ed.), The Blackwell Companion to Sociology of Religion, Oxford: Blackwell, 133-60 
10. Dorwil H., and Mayer, R. 2001. Case Studies and Social Interventions, Vol. II, Université du Québec Press

11. Mouton J. 1996. Understanding social research, Van Schaik Publishers, Hatfield, Pretoria

12. Pickel Gert. 2011. Religionssoziologie - Eine Einführung in zentrale Themenbereiche, pp. 3, 16-24; VS Verlag

13. Döring Nicola, Börtz Jürgen. - Forschungsmethoden und Evaluation in den Sozial- und Humanwissenschaften, 5. Auflage, Springer, 2016

14. Thompson Paul R. 2002, The Edwardians, Routledge Publishing, London

15. Josefina J. Card, Josefina J., \& Kuhn Tamara J. 2015. Archiving: Ethical Aspects, Elsevier Ltd.

16. Bauemer T. L., 1985. Testing a general model of fear of crime: data from a national sample. Journal of Research in Crime and Delinquency, 22 (3): 239-55

17. Lewis D. A. \& Salem, G., 1986. Fear of crime: incivility and the production of a social problem. New Brunswick, $\mathrm{NJ}$ : Transaction Books

18. Corti L., Witzel A., Bishop L. (eds.). 2005, 'Special Issue: Secondary Analysis of Qualitative Data', FQS, Vol 6, No 1, 2005

19. Häder M. 2015. Empirische Sozialforschung - Eine Einführung, 3. Auflage, Springer VS

20. Bourdieu P. 1990. In Other Words: Essays Towards a Reflexive Sociology, Stanford: Stanford University Press

21. Maxfield M. G. 1984. The limits of vulnerability in explaining fear of crime: a comparative neighborhood analysis. Journal of Research in Crime and Delinquency, 21 (3): 233-250 